\title{
'Monga' in northern region of Bangladesh: a study on people's survival strategies and coping capacities
}

\author{
Shitangsu Kumar Paul ${ }^{1 *}$, Md. Nazir Hossain ${ }^{2}$ \& Shudarshan Kumar Ray ${ }^{3}$ \\ ${ }^{1}$ Department of Geography and Environmental Studies, University of Rajshahi, \\ Rajshahi 6205, Bangladesh; ${ }^{2}$ Department of Geography and Enviroment, Shahjalal \\ University of Science \& Technology, Sylhet, Bangladesh; ${ }^{3}$ Battalion 5, Armed Police \\ Battalion, Dhaka, Bangladesh. \\ *Corresponding author: shitangsuk@yahoo.com
}

\begin{abstract}
The objective of this paper is to explore people's survival strategies and coping capacities to combat monga at household level in the northern region of Bangladesh. The agriculture based rural economy, extreme poverty, high percentage of landless, lack of sufficient caloric intake, unemployment of vast agricultural labour force etc. are the root causes of vulnerability to monga in the northern regions specifically few districts of greater Rangpur. Moreover, geographically this region is vulnerable to natural hazards such as floods and droughts. The past records of food shortages and famine reveal that the trend is still continuing in the monga-prone areas. The present study found that the most vulnerable groups in the monga-prone areas were agricultural wage labourers, landless and marginal farmers, female headed households, children, pregnant women and aged people. The present study also found that with a view to cope with the monga, various coping strategies such as selling of labour with advance payment at cheap rate, borrowing of money, selling of assets, looking for work in other areas, dependency on relief, selling of field crops in advance at cheap rate etc. were adopted by the affected households. The present study also found that coping capacity was associated with household head's socio-economic status e.g. level of education, monthly income, types of occupation, etc. Vulnerability to monga was higher for the illiterate and low income groups than the educated and high income groups. The present study argues that the policy makers of Government and NGOs should emphasize on enhancing of coping capacities of poor and marginalized groups through rural centric development, rural employment generation, maximum utilization of agricultural land, proper credit support and agro-based industrialisation in the northern Bangladesh.
\end{abstract}

Keywords: Monga, poverty, famine, coping strategy, coping capacity, Bangladesh.

\section{Introduction}

Bangladesh is one of the most densely populated and disaster prone countries in the world having about 149.77 million people within an area of $147,570 \mathrm{Km}^{2}$ and growth rate of population is 1.37 (BBS, 2012). Floodplain topography and tropical monsoon climate make northern region of Bangladesh vulnerable to various natural calamities such as flood, riverbank erosion, drought and cold waves, all of which occurs more frequently and intensely than other regions of the country (Paul \& Routray, 2010a; Paul et al., 2012; Paul, 2014). Amidst these compelling conditions, the local economy shows little diversification and is heavily dependent on agriculture, which yields only one or sometimes two annual harvest, in contrast 
with three crops per year in more fertile and benign parts of the country (Ara, 2007; Paul \& Routray, 2010b). In this setting, local employment remains limited from mid-September to mid-December. Besides, the landless and poorest people survive on agricultural wage labour, their opportunities and ensuing incomes drop in this period, and trapped in what is called 'monga' a cyclical phenomenon of poverty and hunger; which also termed as seasonal poverty (Elahi \& Ara, 2008). The seasonal poverty is a near famine situation of acute scarcity of employment during the Bangla months of Bhadra-Kartik (September-November). It is commonly known as 'monga' or ' $a b h a b$ '1 (CARE, 2005; Hasan, 2006). It is used to indicate the occurrence of acute deprivation and starvation due to the erosion of purchasing power from the lack of gainful employment opportunities. The monga stricken people, in the northern region, represents 10 percent of the country's total population and occupies 11 percent land of Bangladesh (Rob, 2005). This periodic catastrophe has long been linked with the country's traditional subsistence agriculture system, feudal and tenure arrangement and exploitative dadan ${ }^{2}$ system in rural credit market (Elahi \& Ara, 2008; Paul \& Routray, 2010a). Similarly, transport crisis, inadequate marketing, limited irrigation facilities and employment crisis in the monga prone region increase people's vulnerability to a great extent (Zug, 2006). The root causes of monga are: inequitable distribution of land, high number of poor households being dependent on agricultural labour for their subsistence, limited opportunities for sustainable off-farm economic activities and natural calamities (Zug, 2006; Rahman, 2008). Monga affected people rush to the cities to become rickshaw puller or day labourer, and reduce the quantity of nutritional intake basically reduce number and amount of meals. They consume cheap and sometimes unhygienic products and collect wild growing plants (Zug, 2006; Elahi \& Ara, 2008). Despite monga is an overwhelming silent disaster in the northern Bangladesh but yet it has not received proper and fruitful attention from the Government, Non-government and International Organisations (Elahi \& Ara, 2008).

A number of studies have focused on famine in Bangladesh but not solely on monga; for example concept of poverty and famine by Alamgir, 1975; Muqtada, 1981; Ravillion, 1982; BRAC, 1984; Sen, 1984; Khuda, 1985; Blair, 1986; Rahman, 1986; Rahman \& Hossain, 1995; Hye, 1996; Zug, 2006. Few studies focused on the food production in Bangladesh (Karim \& Levinson, 1979) while others on food planning and scarcity of food in a broad sense (Chen, 1975), causes and forms of food shortage or crisis (Chowdhury, 1986; Murshid, 1986; Shahabuddin, 1989; WFP, 2005) and various aspects of malnutrition due to famine (Haddad, 2002; CARE, 2005; Paul et al., 2012). A number of studies also emphasized on agricultural production, landlessness and seasonality (Alamgir, 1975; Rahman, 1981; Murshid \& Abdullah, 1986; Roy, 1996;) and government role to deal with these issues (Hye, 2002; Hossain, 2004; Khan, 2004; Jahan et al., 2005; Rob, 2005). The review of existing literatures reveals that very limited

\footnotetext{
${ }^{1}$ The state of not having enough money to take care of basic needs such as food, clothing, and housing.

${ }^{2}$ Dadon is an advance payment of money for supplying a particular amount of goods within a particular period.
} 
studies have been conducted by giving in-depth insight on monga and very little attention has given to combat this issue. Therefore, to fill this research gap the present study intends to explore the root causes and particular impacts of monga and assesses people's survival strategies and coping capacities in the study villages. The present study also explores proper mitigation strategies and formulates policy guideline to combat monga in the northern region of Bangladesh.

\section{Materials and methods}

The Madhuram and Kismat Gobdha villages were purposively selected from Lalmonirhat sadar upazila of Lalmonirhat district and Rajarhat upazila of Kurigram district respectively based on the severity of monga impacts. The primary data for the present study were collected through household questionnaire survey, interview with key informants and field observations. A total 86 households were selected as sample from 634 households assuming 90 per cent confidence level through simple random sampling procedure. Both, descriptive and inferential statistics were used to analyse data. Besides, respondents' perception about survival strategy and coping capacity to combat monga were measured using Likert scale.

\section{Results and discussion}

Impacts of monga

Different groups of people in the northern region of Bangladesh are mostly affected by monga. The most vulnerable groups to monga varies according to the income category, educational status, gender characteristics, occupational status and age groups. In this regard, victims of monga are identified as physically disabled and sick people, agriculture wage labour and small vendor, children, women and old age, landless and marginal farmers, female headed households, and disaster affected people such as riverbank erosion, flood and drought. The main monga affected people are those, who have to rely on agricultural labour as their major income source is either on the fields of others or on their own small properties (Bari, 2007). Many of them live from hand to mouth, and if they cannot earn income during the lean season, and face food insecurity (Hye, 2002). There is a general gender dimension concerning the intra-household allocation of food in Bangladesh. According to the World Food Program (WFP) children, disabled, as well as pregnant and breast feeding women face the greatest nutritional risks within the household during monga period (WFP, 2005).

The respondents mentioned that in general monga prolonged less than a month to more than four months. About half of the respondents $(43 \%)$ mentioned that the average duration of monga is 2-3 months and it is 1-2 months for one fourth of $(24.42 \%)$ respondents. The present study found that the extent of monga was relatively prolonged for the villagers of Madhuram village than Kismat Gobdha. It is also found that unavailability of food was higher during prolong monga period, such as $43.0 \%$ of households experienced monga for $2-3$ months, similarly $18.6 \%$ of total household experienced more than 3-4 months of monga and $17.8 \%$ had no availability of food (Table 1). So, it can be mentioned that when monga prolongs, 
unavailability of food also increases. The chi-square test significantly confirms that higher the monga period lesser the food availability and lower the coping capacity.

Table 1. Relationship between duration of monga and availability of food.

\begin{tabular}{|c|c|c|c|c|c|c|c|c|c|c|c|c|}
\hline \multirow{2}{*}{$\begin{array}{c}\text { Availability } \\
\text { of food }\end{array}$} & \multicolumn{2}{|c|}{$\begin{array}{c}<\text { One } \\
\text { month }\end{array}$} & \multicolumn{2}{|c|}{$\begin{array}{c}\text { One-two } \\
\text { months }\end{array}$} & \multicolumn{2}{|c|}{$\begin{array}{c}\text { Two-three } \\
\text { months }\end{array}$} & \multicolumn{2}{|c|}{$\begin{array}{c}\text { Three-four } \\
\text { months }\end{array}$} & \multicolumn{2}{|c|}{$\begin{array}{c}\text { Four- } \\
\text { months }<\end{array}$} & \multicolumn{2}{|c|}{ Total } \\
\hline & $\mathrm{HH}$ & $\%$ & $\mathrm{HH}$ & $\%$ & $\mathrm{HH}$ & $\%$ & $\mathrm{HH}$ & $\%$ & $\mathrm{HH}$ & $\%$ & $\mathrm{HH}$ & $\%$ \\
\hline Yes & 8 & 9.3 & 7 & 8.1 & 8 & 9.3 & 1 & 1.2 & - & - & 24 & 27.9 \\
\hline No & 2 & 2.3 & 14 & 16.3 & 29 & 33.7 & 15 & 17.4 & 2 & 2.3 & 62 & 72.1 \\
\hline Total & 10 & 11.6 & 21 & 24.4 & 37 & 43.0 & 16 & 18.6 & 2 & 2.3 & 86 & 100 \\
\hline$\chi^{2}-$ Test & \multicolumn{12}{|c|}{ Sig. Value $=0.001, \mathrm{df}=4$} \\
\hline
\end{tabular}

The monga is also associated with a major deterioration in the quality of household's health environment during the actual monga period. Many diseases occur in the monga prone areas particularly these are related to malnutrition. Diarrhoea and other diseases occur due to the consumption of wild vegetables and less nutritious items. In such a situation, the women, children and the aged become the worst suffers. Table 2 shows that in the study villages, stomach problem with very high intensity followed by diarrhoea, skin diseases, cold and fever as high intensity based on five point Likert scale.

Table 2. Degree of diseases in the study villages.

\begin{tabular}{|c|c|c|c|c|c|c|}
\hline \multirow[b]{2}{*}{ Diseases } & \multicolumn{2}{|c|}{ Madhuram } & \multicolumn{2}{|c|}{ Kismat Gobdha } & \multicolumn{2}{|c|}{ Total } \\
\hline & $\begin{array}{l}\text { Weighted } \\
\text { Average } \\
\text { Index }\end{array}$ & $\begin{array}{c}\text { Degree of } \\
\text { Impact }\end{array}$ & $\begin{array}{l}\text { Weighted } \\
\text { Average } \\
\text { Index }\end{array}$ & $\begin{array}{l}\text { Degree } \\
\text { of } \\
\text { Impact }\end{array}$ & $\begin{array}{l}\text { Weighted } \\
\text { Average } \\
\text { Index }\end{array}$ & $\begin{array}{l}\text { Degree } \\
\text { of } \\
\text { Impact }\end{array}$ \\
\hline $\begin{array}{l}\text { Stomach } \\
\text { problem }\end{array}$ & 0.84 & $\begin{array}{l}\text { Very } \\
\text { High }\end{array}$ & 0.9 & $\begin{array}{l}\text { Very } \\
\text { High }\end{array}$ & 0.86 & $\begin{array}{l}\text { Very } \\
\text { High }\end{array}$ \\
\hline Diarrhoea & 0.69 & High & 0.79 & High & 0.72 & High \\
\hline $\begin{array}{l}\text { Skin } \\
\text { diseases }\end{array}$ & 0.80 & High & 0.76 & High & 0.79 & High \\
\hline Cold & 0.63 & High & 0.63 & High & 0.63 & High \\
\hline Fever & 0.65 & High & 0.66 & High & 0.658 & High \\
\hline \multicolumn{7}{|c|}{ Criteria for Assessment } \\
\hline Very Low & \multirow{2}{*}{\multicolumn{2}{|c|}{\begin{tabular}{|c|} 
Low \\
$021-0.40$
\end{tabular}}} & oderate & \multicolumn{2}{|c|}{ High } & Very High \\
\hline $0.01-0.20$ & & & $41-0.60$ & $0.61-0.80$ & \multicolumn{2}{|c|}{$0.81-1.00$} \\
\hline
\end{tabular}

Source: Household Survey, 2010.

\section{Household's survival strategies}

In the study villages, people frequently affected by monga and due to it's diverse impacts traditionally people developed various types of survival strategies related to their livelihoods for example selling labour and field crops with advance payment, borrowing, consumption smoothing, selling household assets, seasonal migration, changing occupation etc.

Selling of labour with advance payment at cheap rate

In monga prone areas, selling of labour with advance payment at cheap rate is one of the key coping strategies. Monga affected people know that they will have 
limited income during monga, because they will have limited yield on their own field, or they will remain unemployed. Therefore, some distressed people try to sell their future potentials. Agricultural labourers sell their labour with advance payment at cheap rate. It is found that the members of $61.3 \%$ households sell their labour with advance payment to mahajans. In Madhuram village the members of $70.7 \%$ households sell labour with advance payment which was higher than Kismat Gobdha village (42.9\%). The chi-square result (Sig. value $=0.013, \mathrm{df}=1$ ) confirms significant difference between the two study villages in terms of selling of labour with advance payment (Table 3 ).

Table 3. Selling of labour with advance payment at cheap rate.

\begin{tabular}{|l|c|c|c|c|c|c|}
\hline \multirow{2}{*}{ Response } & \multicolumn{2}{|c|}{ Madhuram } & \multicolumn{2}{c|}{ Kismat Gobdha } & \multicolumn{2}{c|}{ Total } \\
\cline { 2 - 7 } & $\mathrm{HH}$ & $\%$ & $\mathrm{HH}$ & $\%$ & $\mathrm{HH}$ & $\%$ \\
\hline Yes & 41 & 70.7 & 12 & 42.9 & 53 & 61.6 \\
\hline No & 17 & 29.3 & 16 & 57.1 & 33 & 38.4 \\
\hline Total & 58 & 100.0 & 28 & 100.0 & 86 & 100.0 \\
\hline$\chi^{2}$-Test & \multicolumn{4}{|l}{ Sig. Value $=0.013, \mathrm{df}=1$} \\
\hline
\end{tabular}

Source: Field Survey, 2010.

Borrowing

Borrowing is another key ways to survive during monga time for poor households, and is a common strategy among the affected community. Households that were not severely affected by monga also borrowed as well. It is found that nearly $72 \%$ of households borrowed money while the percentage of households borrowed money during monga was higher in Kismat Gobdha village $(85.7 \%)$ than that of Madhuram village $(65.52 \%)$. The $\chi^{2}$-test result (Sig. value $=0.050, \mathrm{df}=1, \alpha=0.05$ ) reveals significant difference between two villages in terms of borrowing money. The affected people borrow from different sources, such as banks, NGOs, relatives and money lenders. It is found that $11.11 \%$ of respondents in both the villages borrowed money from the Government bank, followed by $38.39 \%$ from money lenders, $33.33 \%$ from NGOs, and $17.17 \%$ from relatives. In case of the study villages, $11.86 \%$ respondents in Madhuram village and $11 \%$ respondents in Kismat Gobdha village borrowed from different banks, whereas $37.29 \%$ in Madhuram village and $27.5 \%$ in Kismat Gobdha village borrowed from NGOs. Moreover, highest percentage of respondents had taken loan from money lenders were found in Kismat Gobdha village. Besides, respondents, have taken loan from relatives was higher in Madhuram village than Kismat Gobdha village. The present study also found that $54.87 \%$ of total respondents borrowed for food consumption, $14.16 \%$ for agricultural purposes, $4.42 \%$ for business, $26.55 \%$ for searching work in others areas. In Madhuram village, $55.88 \%$ of respondents mentioned that they take loan for food consumption, whereas in Kismat Gobdha village this figure is $53.34 \%$. On the other hand, in Madhuram village $8.82 \%$ mentioned their purpose of borrowing was for agriculture and in Kismat Gobdha village only $22.22 \%$ mentioned for the same. In Madhuram village, $30.89 \%$ respondents mentioned for investing money in search of work. It is mentionable that majority of the respondents in Madhuram village had taken loan for food 
consumption, because number of landless was higher and level of income was lower than Kismat Gobdha village. So, the vulnerability to monga is higher among the villagers of Madhuram than Kismat Gobdha village. However, borrowing for purchasing food is a vital coping strategy for most of the low income monga affected people in both the villages.

\section{Changes in eating behaviours}

Scarcity of food during monga is a common phenomenon among monga affected communities. When a household face insufficient supply of food, household head, the primary responsible person to feed all the family members usually take different measures to cope with the situation such as reducing the number of meals in a day. It is found that $27.90 \%$ of households in both the villages reduced their meals, $72.10 \%$ relayed on both reducing meal and inexpensive food items. In case of individual villages, $22.41 \%$ households in Madhuram village and $39.28 \%$ households in Kismat Gobdha village reduced their number of meals per day. On the contrary, number of households reduced both the meal and relaying on inexpensive food was higher in Madhuram (77.59\%) than Kismat Gobdha village $(60.72 \%)$. The consumption smoothing was relatively high in Madhuram village because most of the people of this village fall in low and lower middle income groups. The chi-square test result ( $\mathrm{Sig}$. value $=0.077, \mathrm{df}=1$ ) does not confirms significant difference between two villages in terms of changes in eating behaviour. In both of the villages, skipping meal is a common survival strategy. People reduce their food intake both in quality and quantity in two ways, for example stop buying relatively expensive items for their meals in one hand and consume the food items that they do not eat during normal times.

\section{Selling of productive assets}

It is found in both of the study villages that selling of assets is common coping strategy among monga prone communities. The present study found that $84.9 \%$ of households sold their assets during monga in both the villages. Similarly in case of individual village $86.20 \%$ household in Madhuram village and $82.1 \%$ households in Kismat Gobdha village sold their assets. Most common selling items in both the villages are cattle, chicken and trees. Many household head tries to overcome such crisis by mortgaging or selling of land. Moreover, land is considered as a most important asset in rural communities and if people lose this livelihood security severally reduces in the long run. It is also found that $43.80 \%$ of the respondents in Madhuram and 32.81\% in Kismat Gobdha villages sold cattle to overcome the crisis posed by monga. By selling cattle, the concerned farmers had to face tremendous problem during the cultivation season. Because rural people use traditional way of cultivation, so the loss of cattle especially cow/ox adds new hurdles and creates a long term impact on the livelihood of the farmers. Chicken and ducks are other productive assets for rural households, $28.40 \%$ of total respondents in both the villages sold such assets, whereas in Madhuram village $29.52 \%$ and in Kismat Gobdha village $26.56 \%$ respondents respectively sold chicken/duck due to monga. Nearly, $6.67 \%$ households in Madhuram village and $14.06 \%$ in Kismat Gobdha village sold trees. Selling or mortgaging of land is a process of being landless. Few farmers may get back their mortgaging land by repaying loan but at the end they become landless and dispose their broken house, bicycle and corrugated iron sheet etc. 


\section{Alternative occupation}

In monga prone areas people's occupation is seriously affected, especially those who engage in farming and non-farming wage labouring. To combat such occupational crisis they try to find out some alternative occupations, such as pulling rickshaw/van, fishing and small vending etc. It is found that out of total 86 respondents, $42.86 \%$ was engaged in daily labouring, followed by $28.57 \%$ in fishing and $28.57 \%$ in pulling van/rickshaw (Table 4). It is mentionable that number of respondent having alternative occupation is higher in Madhuram village than Kismat Gobdha, and significant proportion was engaged in rickshaw/van pulling.

Table 4. Alternative occupations in the study villages.

\begin{tabular}{|l|c|c|c|c|c|c|}
\hline \multirow{2}{*}{ Occupations } & \multicolumn{2}{|c|}{ Madhuram } & \multicolumn{2}{c|}{ Kismat Gobdha } & \multicolumn{2}{c|}{ Total } \\
\cline { 2 - 8 } & HH & $\%$ & HH & $\%$ & HH & $\%$ \\
\hline Fishing & 18 & 30.93 & 6 & 20.69 & 24 & 28.57 \\
\hline Daily Labour & 24 & 42.27 & 12 & 44.83 & 36 & 42.86 \\
\hline Rickshaw / Van Puller & 16 & 26.80 & 10 & 34.48 & 26 & 28.57 \\
\hline Total & 58 & 100.0 & 28 & 100.0 & 86 & 100.0 \\
\hline
\end{tabular}

Source: Field Survey, 2010.

\section{Selling of field crops with advance payment}

Selling of field crops with advance payment is a common survival strategy for marginal farmers. To overcome the impact of monga farmers sell their field crops in advance at cheap rate. This survival strategy expresses the vulnerable situation of marginal and small farmers during monga period. Due to the selling of field crops in advance marginal and small farmers fall in a severe food crisis during and after monga period. The present study found that $6.9 \%$ respondents of Madhuram village sold their field crops in advance at cheap rate during severe monga, which was lower than Kismat Gobdha village (39.3\%). The number of marginal and small farmers was high in Madhuram village due to the Teesta river erosion and many respondents lost their agricultural land. However, the result of chi-square test (Sig. value $=0.000, \mathrm{df}=1$ ) confirms significant difference between the two villages in terms of selling of fields crops with advance payment (Table 5).

Table 5. Selling of field crops with advance payment.

\begin{tabular}{|l|c|c|c|c|c|c|}
\hline \multirow{2}{*}{ Response } & \multicolumn{2}{|c|}{ Madhuram } & \multicolumn{2}{c|}{ Kismat Gobdha } & \multicolumn{2}{c|}{ Total } \\
\cline { 2 - 7 } & $\mathrm{HH}$ & $\%$ & $\mathrm{HH}$ & $\%$ & $\mathrm{HH}$ & $\%$ \\
\hline Yes & 4 & 6.9 & 11 & 39.3 & 15 & 17.4 \\
\hline No & 54 & 93.1 & 17 & 60.7 & 71 & 82.6 \\
\hline Total & 58 & 100.0 & 28 & 100.0 & 86 & 100.0 \\
\hline$\chi^{2}-$ test & \multicolumn{5}{l}{} \\
\hline
\end{tabular}

Source: Field Survey, 2010.

\section{Seasonal migration of labour}

Seasonal migration is an important survival strategy of the rural poor not only during the times of monga but also other times of the year as well. The present study found that due to joblessness during the monga period, people mainly the males forced to migrate to various other areas especially in the urban localities. 
Local economy in this period is not enough to accommodate the local people in their own areas. Therefore, they migrate to the urban areas as part of their coping mechanism to combat monga. Most of the migrants take shelter in the city slums. It is found that labour migration was higher in Madhuram village $(86.2 \%)$ than Kismat Gobdha (64.3\%). Main reason of this difference is that the local economy is too poor in Madhuram than Kismat Gobdha village. The chi-square test result (Sig. value $=0.019, \mathrm{df}=1$ ) confirms significant difference between the two villages in terms of labour migration (Table 6). This means that seasonal employment is high in Madhuram village than Kismat Gobdha.

Table 6. Seasonal migration of labour in the study villages.

\begin{tabular}{|l|c|c|c|c|c|c|}
\hline \multirow{2}{*}{ Response } & \multicolumn{2}{|c|}{ Madhuram } & \multicolumn{2}{c|}{ Kismat Gobdha } & \multicolumn{2}{c|}{ Total } \\
\cline { 2 - 8 } & HH & $\%$ & HH & $\%$ & HH & $\%$ \\
\hline Yes & 50 & 86.2 & 18 & 64.3 & 68 & 79.1 \\
\hline No & 8 & 13.8 & 10 & 35.7 & 18 & 20.9 \\
\hline Total & 58 & 100.0 & 28 & 100.0 & 86 & 100.0 \\
\hline$\chi 2-$ test & \multicolumn{2}{ll}{} \\
\hline
\end{tabular}

Source: Field Survey, 2010.

\section{Dependency on relief}

Many female headed, aged and disable household head in the study villages were dependent on governmental or non-governmental reliefs. Their economic status, gender, age characteristics or physical disability compelled them to depend on relief. They tried heart and soul to collect a VGD/VGF card from local government office for survival. The present study found that nearly $37.2 \%$ respondent was dependent on relief in both the villages (Table 7). Such findings reveal inadequacy in relief operation in monga prone areas of Bangladesh. The chi-square test result (Sig. value $=0.104, \mathrm{df}=1$ ) does not confirms significant difference between the two study villages in terms of relief operation for monga victims which unveiled relief operation was mostly similar irrespective of village locations. The present study also found that the people of monga affected areas also followed several other coping strategies such as women family members join in income generating activities such as cottage industry, rearing poultry and animal husbandry etc.

Table 7. Dependency on relief in the study villages.

\begin{tabular}{|l|c|c|c|c|c|c|}
\hline \multicolumn{1}{|c|}{$\begin{array}{c}\text { Dependency on } \\
\text { Relief }\end{array}$} & \multicolumn{2}{c|}{ Madhuram } & \multicolumn{2}{c|}{ Kismat Gobdha } & \multicolumn{2}{c|}{ Total } \\
\cline { 2 - 7 } & HH & $\%$ & HH & $\%$ & HH & $\%$ \\
\hline Yes & 25 & 43.1 & 7 & 25.0 & 32 & 37.2 \\
\hline No & 33 & 56.9 & 21 & 75.0 & 54 & 62.8 \\
\hline Total & 58 & 100.0 & 28 & 100.0 & 86 & 100.0 \\
\hline$\chi^{2}-$ test & \multicolumn{2}{|c|}{ Sig. Value $=0.104, \mathrm{df}=1$} \\
\hline
\end{tabular}

Source: Household Survey, 2010.

Household's coping capacity

Monga is a seasonal event, which occurs almost every year in the northern regions of Bangladesh. People cope with the situation using their own knowledge, assets and sometimes by external support from government or non-governmental 
organisations. People's coping capacity is a complex and dynamic process, which is linked with several physical and socio-economic variables. Few variables were selected such as income, education, occupation and duration of monga etc. to understand the coping capacity of people in monga prone areas.

\section{Household income level and coping capacity}

People's vulnerability and coping capacity to monga usually highly associated with their income level. In the present study monthly income of household head is categorised into four classes i.e. Low ( $<2000 \mathrm{Tk})$, Lower Middle (2000-4000Tk.), Upper Middle (4000-6000Tk) and High $(6000 \mathrm{Tk}+)$. It is mentionable that most of the surveyed households fall in category of low (45.3\%) and lower middle income group $(41.9 \%)$. The present study found that most of the high $(80 \%)$ and upper middle $(66.7 \%)$ income groups had availability of food during the period of monga. In the case of low $(87.2 \%)$ and lower middle $(69.4 \%)$ income groups majority of households had not sufficient food. Hence, it is worth mentioning that coping capacity in terms of stockpiling food is higher in high and upper middle income groups and it is less in low and lower middle income groups. Therefore, vulnerability is higher for low and lowers middle income groups than high and upper middle income groups. In case of two study villages income situation and availability of food was relatively better in Kismat Gobdha village than Madhuram. The chi-square result (Sig. value $=0.001, \mathrm{df}=3$ ) confirms significant difference among different incomes groups in terms of the availability of food i.e. higher the income greater the coping capacity in terms of food stockpiling (Table 8). Similarly, high and upper middle income groups have higher accessibility to credit facility than low and lower middle income groups. This hypothesis is supported by chi-square test result ( $\mathrm{Sig}$. value $=0.002, \mathrm{df}=3$ ). The percentage of borrowing money was higher in Madhuram village than Kismat Gobdha village. Most of the households in Madhuram village borrowed money for food consumption, whereas in Kismat Gobdha village mostly people borrowed money to invest in agriculture.

It is also found that households with high and upper middle income groups prefer to reduce the number of meals than relying on less expensive food items. The higher and upper middle income groups have the capability to stockpile food for monga period. In Madhuram village mostly households (77.59\%) prefer to both reducing meal number and relaying on less expensive food items. Upper middle income group cope with the monga without selling of assets. On the contrary, selling tendency of assets was higher among the households with lower middle income group, because they try to cope with the situation by selling whatever assets they have. On the contrary, lower income group has less assets to sell and more remain more vulnerable to monga and less ability to cope with the situation. The chi-square results shows significant association between level of income and selling of assets i.e. higher the income lower the selling of assets and greater the coping capacity (Table 8 ).

Education level and coping capacity

The present study found that level of education of household head is significantly associated with availability of food. All the household head having college level 
education had availability of food during the period of monga. On the contrary, availability of food decreases gradually with the decrease in the level of education of household head. It is quite interesting that the entire household having college level education $(100 \%)$ had availability of food, whereas more than three quarter of illiterate household heads did not have adequate food. The chi-square test result (Sig. value $=0.043, \mathrm{df}=3$ ) confirms such difference i.e. higher the education level greater the food availability and higher the coping capacity. It has been noticed that people's eating behaviour was also associated with level of education. Most of the college level educated household heads preferred to reduce meal number rather than relying on less expensive food items. It might be due to higher educated people had higher income and remain food secure during monga period. Besides, most of the diseases are linked with below quality food, on which mostly illiterate people relay on. Similarly most of the people in Kismat Gobdha village preferred to reduce meal number rather than relying on less expensive food items. The chisquare result ( $\mathrm{Sig}$. value $=0.034, \mathrm{df}=3$ ) confirms the significant difference between different education level in terms of changes eating behaviour i.e. higher the education level lesser the relying on less expensive food or reduce number of meals and higher the coping capacity (Table 9).

Table 8. Relationship between level of income of household head with relevant variables.

\begin{tabular}{|c|c|c|c|c|c|c|c|c|c|c|}
\hline \multirow{3}{*}{ Variables } & \multicolumn{10}{|c|}{ Level of income of Household Head } \\
\hline & \multicolumn{2}{|c|}{$\begin{array}{c}\text { Low } \\
(<2000 \mathrm{Tk})\end{array}$} & \multicolumn{2}{|c|}{$\begin{array}{l}\text { Lower } \\
\text { Middle } \\
(2000- \\
\text { 4000Tk) }\end{array}$} & \multicolumn{2}{|c|}{$\begin{array}{c}\text { Upper } \\
\text { middle } \\
(4000- \\
6000 \mathrm{Tk})\end{array}$} & \multicolumn{2}{|c|}{$\begin{array}{c}\text { High } \\
\left(6000 \mathrm{Tk}^{+}\right)\end{array}$} & \multicolumn{2}{|c|}{ Total } \\
\hline & $\mathrm{HH}$ & $\%$ & $\mathrm{HH}$ & $\%$ & $\mathrm{HH}$ & $\%$ & $\mathrm{HH}$ & $\%$ & $\mathrm{HH}$ & $\%$ \\
\hline \multicolumn{11}{|c|}{ Availability of food supply } \\
\hline Yes & 5 & 12.8 & 11 & 30.6 & 4 & 66.7 & 4 & 80 & 24 & 27.9 \\
\hline No & 34 & 87.2 & 25 & 69.4 & 2 & 33.3 & 1 & 20 & 62 & 72.1 \\
\hline Total & 39 & 100 & 36 & 100 & 6 & 100 & 5 & 100 & 86 & 100 \\
\hline$\chi^{2}-$ test & \multicolumn{10}{|c|}{ Sig. value $=0.001 \mathrm{df}=3$} \\
\hline \multicolumn{11}{|l|}{ Borrowing money } \\
\hline Yes & 20 & 51.3 & 31 & 86.1 & 6 & 100 & 5 & 100 & 62 & 72.1 \\
\hline No & 19 & 48.7 & 5 & 13.9 & - & - & - & - & 24 & 27.9 \\
\hline Total & 39 & 100 & 36 & 100 & 6 & 100 & 5 & 100 & 86 & 100 \\
\hline$\chi^{2}-$ test & \multicolumn{10}{|c|}{ Sig. value $=0.002 \mathrm{df}=3$} \\
\hline \multicolumn{11}{|c|}{ Changes in eating behaviour } \\
\hline $\begin{array}{l}\text { Reduce the } \\
\text { number of meal }\end{array}$ & 4 & 10.3 & 11 & 30.6 & 5 & 83.3 & 4 & 80 & 24 & 27.9 \\
\hline $\begin{array}{l}\text { Both reduce meal } \\
\text { and relay on less } \\
\text { expensive food }\end{array}$ & 35 & 89.7 & 25 & 69.4 & 1 & 16.7 & 1 & 20 & 62 & 72.1 \\
\hline Total & 39 & 100 & 36 & 100 & 6 & 100 & 5 & 100 & 86 & 100 \\
\hline$\chi^{2}-$ test & \multicolumn{10}{|c|}{ Sig. value $=0.000, \mathrm{df}=3$} \\
\hline \multicolumn{11}{|l|}{ Selling of assets } \\
\hline Yes & 35 & 89.7 & 33 & 91.7 & 4 & 66.7 & 1 & 20 & 73 & 84.9 \\
\hline
\end{tabular}




\begin{tabular}{|l|l|l|l|l|l|l|l|l|l|l|}
\hline No & 4 & 10.3 & 3 & 8.3 & 2 & 33.3 & 4 & 80 & 13 & 15.1 \\
\hline Total & 39 & 100 & 36 & 100 & 6 & 100 & 5 & 100 & 86 & 100 \\
\hline$\chi^{2}-$ test & \multicolumn{1}{|l|}{ Sig. value $=0.000, \mathrm{df}=3$} \\
\hline
\end{tabular}

Source: Household Survey, 2010.

Table 9. Association of education level of household head with some relevant variables.

\begin{tabular}{|c|c|c|c|c|c|c|c|c|c|c|}
\hline \multirow{3}{*}{ Variables } & \multicolumn{10}{|c|}{ Level of Education } \\
\hline & \multicolumn{2}{|c|}{ Illiterate } & \multicolumn{2}{|c|}{$\begin{array}{l}\text { Primary } \\
\text { School }\end{array}$} & \multicolumn{2}{|c|}{$\begin{array}{l}\text { Secondary } \\
\text { School }\end{array}$} & \multicolumn{2}{|c|}{ College } & \multicolumn{2}{|c|}{ Total } \\
\hline & $\mathrm{HH}$ & $\%$ & $\mathrm{HH}$ & $\%$ & $\mathrm{HH}$ & $\%$ & $\mathrm{HH}$ & $\%$ & $\mathrm{HH}$ & $\%$ \\
\hline \multicolumn{11}{|c|}{ Availability of food } \\
\hline Yes & 13 & 23.2 & 7 & 33.3 & 3 & 42.9 & 2 & 100.0 & 25 & 29.1 \\
\hline No & 43 & 76.8 & 14 & 66.7 & 4 & 57.1 & - & - & 61 & 70.9 \\
\hline Total & 56 & 100.0 & 21 & 100.0 & 7 & 100.0 & 2 & 100.0 & 86 & 100.0 \\
\hline$\chi^{2}$ - test & \multicolumn{10}{|c|}{ Sig. value $=0.043, \mathrm{df}=3$} \\
\hline \multicolumn{11}{|c|}{ Changes in eating behaviour } \\
\hline $\begin{array}{l}\text { Reduce the } \\
\text { number of } \\
\text { meal }\end{array}$ & 15 & 26.8 & 4 & 19.0 & 3 & 42.9 & 2 & 100.0 & 24 & 27.9 \\
\hline $\begin{array}{l}\text { Both reduce } \\
\text { meal number } \\
\text { and relay on } \\
\text { less } \\
\text { expensive } \\
\text { food }\end{array}$ & 41 & 73.2 & 17 & 81.0 & 4 & 57.1 & - & - & 62 & 72.1 \\
\hline Total & 56 & 100.0 & 21 & 100.0 & 7 & 100.0 & 2 & 100.0 & 86 & 100.0 \\
\hline$\chi^{2}-$ test & \multicolumn{10}{|c|}{ Sig. value $=0.034, \mathrm{df}=3$} \\
\hline
\end{tabular}

Source: Household Survey, 2010.

\section{Occupation and coping capacity}

Occupation of household head is an important variable which influence the coping capacity and occupation can also be directly affected by monga. Income level of the household is closely linked with the household head's occupation. For example, crop production is directly affected by drought for households depend on farm income only. On the other hand, non-farm households were mostly nonagricultural labour who becomes jobless during monga period, but service holders were not directly affected by monga. It is found that majority of the household head having farming occupation fall in the income category of 2000-6000 Taka per month. Majority of daily labour and small vendors fall in the income category of $<4000$ taka and majority of service holders fall in category of 4000-6000 taka (Table 10). Therefore, income level is relatively better for service holders than farmers and day labourers. Hence, farmers and wage labour were most vulnerable and having less coping capacity than service holder.

It is also found that household head engaged in service, $100.0 \%$ of them had availability of food. On the other hand, nearly $27.0 \%$ of farmer and $22.2 \%$ of wage labour and small vendors had availability of food during monga. It reveals that mostly wage labour had unavailability of food which represents their less coping 
capacity. Therefore, service holders were mostly secure and wage labour and small vendors were most insecure during monga. The chi-square result also confirms availability of food was significantly differing among various occupational groups. Hence, coping capacity in terms of food availability was higher for service holder than farmer and wage labour. On the other hand, if we consider borrowing of money during monga, was higher among labour and small vendors followed by farmers and service holder. Borrowing for meeting expanses was comparatively lower among wage labour. It is because labour class becomes jobless during prolonged monga and borrowed money from money lender with highest interest rate. This virtually increases their vulnerability to monga or forms vicious cycle of poverty for this occupational group. On the other hand, farmers borrowed money to invest in agriculture, service holder had stable income, and less likely to borrow money than other occupational groups. Such findings unveiled that coping capacity against monga was higher among service holders than wage labour and small vendors.

Table 10. Relationship between primary occupations of household head with availability of food and borrowing.

\begin{tabular}{|c|c|c|c|c|c|c|c|c|}
\hline \multirow[t]{2}{*}{ Variables } & \multicolumn{2}{|c|}{$\begin{array}{l}\text { Farming and } \\
\text { Farm Labour }\end{array}$} & \multicolumn{2}{|c|}{$\begin{array}{l}\text { Non-Farm Labour } \\
\text { and Small Vendor }\end{array}$} & \multicolumn{2}{|c|}{ Service } & \multicolumn{2}{|c|}{ Total } \\
\hline & $\mathrm{HH}$ & $\%$ & $\mathrm{HH}$ & $\%$ & $\mathrm{HH}$ & $\%$ & $\mathrm{HH}$ & $\%$ \\
\hline \multicolumn{9}{|c|}{ Availability of food } \\
\hline Yes & 20 & 27.0 & 02 & 22.2 & 03 & 100.0 & 25 & 29.1 \\
\hline No & 54 & 73.0 & 07 & 77.8 & - & - & 61 & 70.9 \\
\hline Total & 74 & 100.0 & 09 & 100.0 & 03 & 100.0 & 86 & 100.0 \\
\hline$\chi^{2}-$ Test & \multicolumn{8}{|c|}{ Sig. Value $=0.022, \mathrm{df}=2$} \\
\hline \multicolumn{9}{|c|}{ Borrowing money for meeting expenditure } \\
\hline Yes & 51 & 68.9 & 5 & 55.6 & 3 & 100.0 & 59 & 68.6 \\
\hline No & 23 & 31.1 & 4 & 44.4 & - & - & 27 & 31.4 \\
\hline Total & 74 & 100.0 & 9 & 100.0 & 3 & 100.0 & 86 & 100.0 \\
\hline$\chi^{2}-$ Test & \multicolumn{8}{|c|}{ Sig. Value $=0.352, \mathrm{df}=2$} \\
\hline
\end{tabular}

Source: Household Survey, 2010.

Government and NGOs' activities to combat monga

So far, different types of measures have been taken by the GOs and NGOs with a view to eradicate monga and alleviation of seasonal poverty from the northern part of Bangladesh. Therefore, according to the respondents, the severity of monga has been lessened during the last two decades. The Government of Bangladesh has been trying to assist the victims of monga by providing a US\$ 295 million programme which provides employment for two million heads of families for 75 days during the monga season. In earlier years, efforts to counteract the effects of monga were made through Government test relief and other programmes, and also by 'cash-for-work' interventions through NGOs such as Rangpur-Dinajpur Rural Services (RDRS), Bangladesh. RDRS also carried out skills training and crop diversification from the mid 1970s. A national programme namely Vulnerable Group Development (VGD) integrating food insecurity and nutrition issues with development and income generating activities for poor households in food insecure areas is also in operation to alleviate poverty (Holmes et al., 2008). For 
two years this programme transfers monthly food rations, as well as services such as income generating skills training. The programme also works with micro-credit service providers (Holmes et al., 2008). Another measure is the Chars Livelihoods Programme (CLP) includes a monthly stipend for 18 months of 300 Taka per month, infrastructure development, social development training, seasonal work and promote entrepreneurship in the agricultural and non-farm sectors (Holmes et al., 2008). Besides, Programmed Initiative for Monga Eradication (PRIME) was also undertaken by Palli Karma-Sahayak Foundation (PKSF), a micro-finance institution in northern Bangladesh (Holmes et al., 2008). The PKSF provide employment opportunities for the monga season, emergency credit for households with a slightly higher income, consumption loans, remittance services and a carefully designed flexible credit support system (Holmes et al., 2008). The aim is to build beneficiaries' coping capacity, and their skills and resources to secure their own futures (Holmes et al., 2008). The programme of Bangladesh Rural Advancement Committee (BRAC) involves in the transfer of productive assets worth of 8,000 to 13,000 Taka to the poorest households in northern Bangladesh (Holmes et al., 2008). Furthermore, it provides intensive training and support on how to manage these assets, as well as a daily stipend until the assets start producing an income (approximately 300 Taka per month) (Holmes et al., 2008). The programme also subsidises health and legal services, water and sanitation provision and the development of supportive community networks (Holmes et al., 2008).

The present study found that nearly $70.0 \%$ of households had not adequate food to meet their daily requirements during monga. Significant difference was found between two villages, because majority of respondents in Kismat Gobdha village stockpiled food or had buying capacity from market, where as in Madhuram village a large number of respondents were landless and did not have ability to stockpile food to overcome the crisis. The Chi-square test result (Sig. value $=0.014$, $\mathrm{df}=1$ ) confirms the significant difference between the two villages. The dependency on government and non-governmental food assistance was higher in Madhuram village than Kismat Gobdha village. The present study also found that the respondents in both study villages were moderately satisfied on government's food relief operation. On the other hand, respondents in Kismat Gobdha village were dissatisfied on nongovernmental food relief programmes based on five point Liker scale (Table 11).

Table 11. Level of satisfaction of people on food relief by Government and NGOs.

\begin{tabular}{|c|c|c|c|c|c|c|c|}
\hline \multirow[b]{2}{*}{ Organisations } & \multicolumn{3}{|c|}{ Madhuram } & \multicolumn{2}{|c|}{ Kismat Gobdha } & \multicolumn{2}{|r|}{ Total } \\
\hline & WAI & \multicolumn{2}{|c|}{$\begin{array}{c}\text { Level of } \\
\text { Satisfaction }\end{array}$} & WAI & $\begin{array}{c}\text { Level of } \\
\text { Satisfaction }\end{array}$ & WAI & $\begin{array}{c}\text { Level of } \\
\text { Satisfaction }\end{array}$ \\
\hline Government & 0.55 & \multicolumn{2}{|c|}{$\begin{array}{l}\text { Moderately } \\
\text { Satisfied }\end{array}$} & 0.42 & $\begin{array}{l}\text { Moderately } \\
\text { Satisfied }\end{array}$ & 0.52 & $\begin{array}{c}\text { Moderately } \\
\text { Satisfied }\end{array}$ \\
\hline NGO & 0.54 & \multicolumn{2}{|c|}{$\begin{array}{l}\text { Moderately } \\
\text { Satisfied }\end{array}$} & 0.40 & Dissatisfied & 0.51 & $\begin{array}{c}\text { Moderately } \\
\text { Satisfied }\end{array}$ \\
\hline \multicolumn{8}{|c|}{ Criteria for Assessment } \\
\hline $\begin{array}{l}\text { Strongly } \\
\text { Dissatisfied }\end{array}$ & \multicolumn{2}{|c|}{ Dissatisfied } & \multicolumn{2}{|c|}{$\begin{array}{l}\text { Moderately } \\
\text { Satisfied }\end{array}$} & Satisfied & \multicolumn{2}{|c|}{ Strongly Satisfied } \\
\hline $0.01-0.20$ & \multicolumn{2}{|c|}{$0.21-0.40$} & \multicolumn{2}{|c|}{$0.41-0.60$} & $0.61-0.80$ & \multicolumn{2}{|c|}{$0.81-1.00$} \\
\hline
\end{tabular}


Source: Household Survey, 2010. Note: WAI= Weighted Average Index

The present study found that monga is a seasonal scarcity of employment and hence household incomes leading forward the lack of access to food amongst rural poor landless families. It is a phenomenon created by various factors that are partly man made and partly determined by nature. It is the temporal coincidence of different problems which have a large scale negative impact on the livelihoods of the rural poor in a specific time of the year. The present study found that the people of monga affected areas practise various coping strategies to survive in this lean period in order to meet the basic needs. It also reveals that borrowing, selling household assets and livestock at cheap price, taking loan from moneylender with a high rate of interest, changing eating behaviour, reducing consumption of essential goods, temporary migration of labourers during the pre-harvest lean period, selling of standing crops with advance payment at cheap rate depending on food relief by extreme poor, involving in income generating activities by female, changing occupation by household head etc. are the most commonly practised coping and survival strategies adopted by monga victims. Borrowing and selling of assets and changes in eating behaviour is common survival strategies in both the study villages. Moreover, coping capacity against monga is higher among the literate, high income and stable occupational groups than the illiterate and low income groups. In respect of monga alleviation activities, the government has a participatory role through its own micro-credit giving organisations as well as other programmes designed to mitigate sufferings from extreme poverty. The NGOs are also doing a reasonably good job in extending micro-credit and carrying out of multi-faceted programmes to address the problem of monga with a view to meet the monga induced food insecurity. The present study advocates that the Government and NGOs should give more emphasis on long-term rural centric development, rural employment generation, maximum utilization of agricultural land through diversification of agriculture, utilization of char land, management of natural disasters in a sustainable way, proper credit support for marginal farmers and agro-based industrialisation in the northern Bangladesh. Preventing monga sustainably requires reducing long-term risk by preventing negative coping strategies (such as selling productive assets) and enhancing coping capacities of poor and marginalized groups of people through Government and NGOs' assistances, and proper and regular monitoring is needed to create monga resilient communities in northern regions of Bangladesh.

\section{References}

Alamgir, M. 1975. Poverty, inequality and social welfare: Measurement, evidence and policies. Journal of BIDS, 3(2): 153-180.

Ara, I. 2007. The environmental context of the monga in northern Bangladesh. The Journal of Geography, 26: 22-34.

Bari, S. 2007. Consigning Monga to the museum. The Daily Star, Dhaka: 18 April 2007.

BBS (Bangladesh Bureau of Statistics). 2012. Population census, 2011, Final Report. Bangladesh Bureau of Statistics, Dhaka.

Blair, C. 1986. Indian Famine. Agricole Publishing Academy, New Delhi. 
BRAC (Bangladesh Rural Advancement Committee). 1984. Peasant perceptions: famines, credit needs, sanitation. Bangladesh Rural Advancement Committee, Dhaka.

CARE (Cooperative for Assistance and Relief Everywhere). 2005. Monga in northern Bangladesh. http://www.carebangladesh.org/, Cooperative for Assistance and Relief Everywhere.

Chen, L.C. 1975. An Analysis of per capita food grain availability, consumption and requirements in Bangladesh: A systematic approach to food planning. Journal of BIDS. 18(2): 101-124.

Chowdhury, N. 1986. Public food grain distribution system in Bangladesh in the post liberation period: a historical profile. Journal of BIDS, 14 (3): 94-110.

Elahi, K.M. \& Ara, I. 2008. Understanding the Monga in northern Bangladesh. Academic Press and Publishers Library, Dhaka.

Haddad, L. Pena, C. \& Nishida, C. 1996. Food security and nutrition implications of intrahousehold bias: a review of literature. International Food Policy Research Institute, Washington, DC.

Hasan, A. A. M. 2006. Looking into the institutional response to Monga. Bangladesh Legal Aid and Services Trust, Dhaka.

Holmes, R., Farrington, J., Rahman, T. \& Slater, R. 2008. Extreme poverty in Bangladesh: protecting and promoting rural livelihoods. Overseas Development Institute, London.

Hossain, M. 2004. Containing Monga in northern districts. The Daily Star, Dhaka: 19 May 2009.

Hye, H.A. 1996. Below the line: rural poverty in Bangladesh. University Press Limited, Dhaka.

Hye, H.A. 2002. Kepping Monga at bay. Dhaka: The Daily Star, Dhaka: 15 November 2002.

Jahan, S. Karim, A. \& Hassan, S.Z. 2005. Monga: Legal responsibilities of government. The Daily Star, Dhaka:12 December 2005.

Karim, R., \& Levinson, F.J. 1979. A missing dimension of food and nutrition policy in Bangladesh. Journal of BIDS, 7(1): 99-106.

Khan, M. 2004. Poverty rises: Monga drives poor to city. Star weekend magazine, The Daily Star, Dhaka: 3 November 2004.

Khuda, B. 1985. Pattern of employment in a rural area of Bangladesh. Journal of BIDS. 13(2): 33-56.

Muqtada, M. 1981. Poverty and famine in Bangladesh. Journal of BIDS. 9(1): 1-34.

Murshid, K.A.S. \& Abdullah, A.A. 1986. Inter district changes and variation in landlessness in Bangladesh. Journal of BIDS, 10(1): 97-108.

Murshid, K.A.S. 1986. Instability in food grain, production in Bangladesh: nature, levels and trends. Journal of BIDS, 14(2): 115-129.

Paul S.K. 2014. Determinants of evacuation response to cyclone warning in coastal areas of Bangladesh: a comparative study. Oriental Geographer, 55(1-2):57-84.

Paul, S.K. \& J.K. Routray, 2010a. Flood proneness and coping strategies: the experiences of two villages in Bangladesh, Disasters, 34(2): 489-508.

Paul, S.K., \& Routray, J.K. 2010b. Household response to cyclone and induced surge in coastal Bangladesh: coping strategies and explanatory variables. Natural Hazards, 57(2): 477-499.

Paul, S.K., Paul, B.K. \& Routray, J.K. 2012. Post-cyclone Sidr nutritional status of women and children in coastal Bangladesh: an empirical study. Natural hazards, 64(1): 19-36. 
Rahman, A. 1986. Poverty alleviation and the most disadvantaged groups in Bangladesh agriculture. Journal of BIDS. 18(1): 29-58.

Rahman, H.Z. \& Hossain, M. 1995. Rethinking rural poverty: Bangladesh as a case Study. University Press Limited, Dhaka.

Rahman, H.Z. 1995. Mora kartik: seasonal deficits and the vulnerability of the rural poor. In: H.Z. Rahman and M. Hossain (eds.) Re-thinking rural poverty: Bangladesh as a case study. Sage Publications, New Delhi: 234-53.

Rahman, R.I. 1981. Implication of seasonality of rural labour use pattern: evidence from two villages in Bangladesh. Journal of BIDS. 9(1): 77-96.

Ravillion, M. 1982. Agricultural wages in Bangladesh before and after the 1974 famine. Journal of BIDS. 10(1): 75-89.

Rob, A. 2005. Monga: contemplating solutions. The Daily Star, Dhaka: 11 November 2005.

Roy, D.K. 1996. Poverty alleviation and trade policy reform in Bangladesh: some related issues. Journal of BIDS, 24(1\&2): 189-205.

Sen, A. 1984. Poverty and famines: an essay on entitlement and deprivation. Oxford University Press, Delhi.

Shahabuddin, Q. 1989. Pattern of food consumption in Bangladesh: an analysis of household expenditure survey data. Journal of BIDS, 17(3): 101-117.

UN 2008. Bangladesh: Initiatives to tackle Monga. Retrieved from: http://www.irinnews. org/report/80898/bangladesh-initiatives-to-tackle-monga on 16 October 2008. UN Office for the Coordination of Humanitarian Affairs.

WFP 2005. Bangladesh Food security brief. Retrieved from: http://www.fao.org on 16 October 2008. World Food Program, New York.

Zug, S. 2006. Monga-seasonal food insecurity in Bangladesh: bringing the information together. Journal of Social Studies, 111: 21-39. 